\title{
Fedme på nynorsk
}

\section{2010 blei ordet fedme godkjent på nynorsk, men det finst framleis ikkje i ordbøkene.}

«Det var særleg samfunnsfenomenet fedme som skapte behov for eit abstrakt substantiv på nynorsk», jamfør Språkrådet (1). Tidlegare, det vil seie før 2010, kunne ein til dømes nytte ord som feitleik, feite og fite/ fete (1). Men i 2010 godkjende altså fagrådet for normering i Språkrådet å ta inn ordet fedme i nynorske ordbøker (1).

I fagtekstar om fedmekirurgi finst eit språkleg mangfald på nynorsk: kirurgisk behandling for sjukleg overvekt, feiteoperasjonar og kirurgisk behandling ved feite er brukt om det same $(2,3)$.

Internasjonalt skil ein mellom overvekt og fedme. På engelsk kallast det overweight og obesity. Overvekt er definert som kroppsmasseindeks (BMI) $\geq 25$, medan fedme brukast om $\mathrm{BMI} \geq 30(4,5)$.

\section{Sjukleg overvekt - alvorleg fedme} Sjukleg overvekt blir brukt om BMI $\geq 40$, eller $\geq 35$ med vektrelatert sjukdom (6), og er ei omsetting av det engelske morbid obesity. Sjukleg overvekt er likevel ikkje heilt godt, fordi overvekt betyr noko mindre tungt enn fedme, jamfør kroppsmasseindeksen. I ein fersk artikkel i Tidsskriftet undersøkte Strømmen og medarbeidarar mellom anna kva uttrykk for fedme pasientar vurderte som passande eller upassande. Dei fann at brukarane føretrakk nøytrale omgrep som «vekt» og «overvekt», medan «feit» og «sjukleg overvekt» var orda flest meinte var upassande (7).
Alvorleg fedme (severe obesity) er brukt synonymt med sjukleg overvekt $i$ ein del av faglitteraturen internasjonalt. Dette omgrepet har fleire fordelar. Det kan oppfattast som meir nøytralt enn sjukleg overvekt og gir høve til mangfald utover det språklege: Ein kan skrive om vekttilstandar i dei høge BMI-klassane, utan nødvendigvis å definere det som sjukdom. Det vil seie at språket opnar opp for fleire perspektiv enn det medisinske og helsefaglege.

Sjukleg overvekt er mest etablert som omgrep i Noreg, men også alvorleg fedme førekjem. Eg har sjølv bevega meg frå å bruke sjukleg overvekt til å bruke alvorleg fedme på grunn av at uttrykka har ulik valør og verdilading. Eg får variert respons frå helsearbeidarar på det. Nokon tykkjer det er fint å sleppe «sjukleg» knytt til overvekt, andre undrar seg over om vi treng fleire ord for det same.

\section{Eli Natvik}

Eli.Natvik@helse-forde.no

Senter for helseforsking

Helse Førde

Eli Natvik (f. 1973) er fysioterapeut og har disputert på doktoravhandlinga Carrying the weight of uncertainty: Patients' long-term experiences after bariatric surgery.

\section{Litteratur}

1. Språkrådet. Finst fedme? www.sprakradet no/ Vi-og-vart/hva-skjer/Aktuelt-ord/Finst-fedme/ (16.10.2015)

2. Andersen JR, Stokke MH, Tøsdal MB et al. Livsstilsbehandling $\mathrm{i}$ institusjon - oppfølging seks år etter. Sykepleien Forskning 2013: 8: 36-44. https://sykepleien.no/forskning/2013/01/ livsstilsbehandling-i-institusjon-oppfolging-seksar-etter (16.10.2015).

3. Nasjonalt råd for prioritering i helse- og omsorgstjenesten. Årsrapport 2014.

www.kvalitetogprioritering.no/r\%C3\%A5det/ publikasjoner/_attachment/15763?_ts=14cbcfc0de6 (16.10.2015).

4. Folkehelseinstituttet. Kroppsmasseindeks (KMI) og helse. www.fhi.no/tema/overvekt-og-fedme/ kroppsmasseindeks-kmi (16.10.2015).

5. World Health Organization. BMI classification. http://apps.who.int/bmi/index.jsp?introPage= intro 3.html (16.10.2015).

6. Våge V. Overvekt, fedme, sjukleg overvekt. Tidsskr Nor Lægeforen 2007; 127: 1 .

7. Strømmen M, Bakken IJ, Andenæs E et al. Fet, feit eller bare overvektig? Tidsskr Nor Legeforen 2015. 135: $1732-6$

Motteke 20.10. 2015 og godkjent 25.10. 2015. Redaktør: Erlend Hem.

Publisert først på nett. 